\title{
Iranians in 9th Century Egypt
}

\author{
Lucian Reinfandt
}

The Islamic caliphate was an empire of migration, and one is tempted to ask whether migration was indeed the backbone of Islam. The hijra (lit. "migration") of the prophet Muhammad in 622 A.D. from Mecca to Medina became the blueprint for all later migration. ${ }^{1}$ During the Arab conquests of the 7 th and early 8th centuries, Arab tribes migrated and settled in all parts of the new empire as a military and political elite separated by religion from non-Muslim population majorities. ${ }^{2}$ Another phenomenon was a long-distance trade with networks of traders traveling over the Silk Road and the Indian Ocean, the proverbial Sindbad being but a representative for many real ones. ${ }^{3}$ Thirdly, there was a zest for learning in Islamic culture, which is summarized by a famous saying of the prophet Muhammad ("seek knowledge even as far as China!"). ${ }^{4}$ Migration between the urban intellectual centres of North Africa and the Middle East was a prevalent phenomenon during the whole era of pre-modern Islam, and celebrities such as Ibn Khaldun of Ibn Battuta (both 14th century) are only two examples out of many. Finally, there is the obligation for every Muslim to undertake the pilgrimage to Mecca and Medina at least once in a lifetime, which caused the regular movement of many pilgrims on an annual basis through all parts of the Muslim world. ${ }^{5}$

1 A variant understanding of the word hijra in the sense of "conversion to Islam", as is used by e.g. Lapidus, "Evolution of Muslim Urban Society", p. 27, is discussed in Crone, "First-Century Concept of Hiğra". - The citation of papyrus editions is following the convention of the ISAP Checklist of Arabic Documents https://www.naher-osten.lmu.de/isapchecklist [accessed 6 January 2020], but see also the list of papyrological sources at the end of this chapter. Dates of events are given according to the Christian era. Dates of papyrus documents are given both according to the Hijra and the Christian calendar (e.g. 3rd/9th century).

2 For general information on Arab tribal migration in the time of conquests see Ashtor, Social and Economic History, pp. 10-12; Donner, Early Islamic Conquests, passim; Berger, "Medieval Era Migrations", pp. 2254-2256. According to to the 9th century historian al-Kindī, no less than 3000 families of the Arab tribe of Qays were transferred to Egypt under the rule of Hishām in 109/727; cf. Gottschalk, "Dīwān", p. 327. About a possible understanding of the settlement of Arabs in the course of the conquests as a move of colonisation see Crone, "Post-Colonialism".

3 Ashtor, Social and Economic History.

4 Ashtor, "Mouvement migratoire", p. 194 n. 69.

5 About early pilgrimage in Islam see now Sijpesteijn, "An Early Umayyad Papyrus Invitation".

(C) LUCIAN REINFANDT, 2020 | DOI:10.1163/9789004425613_009

This is an open access chapter distributed under the terms of the CC BY-NC 4.o Licensen. Reinfandt - 9789004425613 
One has to distinguish between a temporary and a permanent form of migration, however. Both kinds had differing consequences for migrants and host societies alike. ${ }^{6}$ Another distinction should be about the question whether regional movement was politically or militarily motivated, or whether it was in search of labour. While the former was a trigger of phenomena such as the Arab conquests during the 7 th and 8th centuries, or the Turkish domination of the empire during the 9th and 1oth centuries, the latter was a cause of more smooth forms of migration, such as that of administrators with a Persian or Iranian background, such as Khurāsānians or Central Asians who moved from east to west through the lands of Islam.

In the following will be shown the role of a transregional elite of administrators with an eastern, and possibly Iranian, background during the gth century A.D. and with a particular emphasis on aspects of their social and geographic mobility. Such a moving elite was created not only by the military and the religious establishment, but also by investing landowners and networks of longdistance merchants. Their participation in governance and administration is essential for understanding the intricate workings of the early Islamic Empire and how the caliphal administration controlled and integrated diverse regions and populations while securing the interests of the empire at large. It would be of crucial interest to see how an eastern transregional elite with a specific administrative expertise interacted with the local population and how they balanced their relationships with other regional elites in Egypt, on the one hand, and central caliphal authorities on the other. It would also be of importance to ask whether a shift from one imperial elite (Arab, Khurāsānian, Central Asian, and others) to another was a sign of failure or rather an improvement in terms of stability and efficiency of rule, and which existing networks and emerging institutions helped elites to connect the empire and its diverse regions in terms of tribal affiliation, family policies, clientelism, and strategic appointments.

Arabic papyri from Egypt display an eastern cultural influence on a local society along the Nile during the 9 th and 1oth centuries. They may even witness a physical presence of humans belonging to an administrative elite of Iranian origin in Egypt as well. This presence was not restricted to the urban centre of al-Fustat but may be traced along the find places in the Egyptian hinterland and thus give a profile of settlement unattainable by other sources. There is an occasional mentioning of individuals in the papyri with Persian

6 Still today migrants from Egypt who live in Europe would distinguish between safar (meaning "travel", i.e. the temporary residence) and hijra (meaning "migration", i.e. the permanent residence and the "leaving behind" of a previous life). I am grateful to Lea Müller-Funk (Amsterdam) for this information. 
(and Turkish) personal names. Some of them were located in the offices of high-level administration in al-Fustat, but others were from more regional centres. ${ }^{7}$ Moreover, the language of official papyri from Egypt show changes in the administrative terminology in this province of the caliphate which may have been caused by a presence of officials with an Iranian background on more local levels of administration already in pre-Tulunid Egypt, i.e. before the early 9th century. And finally yet importantly, the mentioning of a few luxury goods with a non-Egyptian but seemingly eastern provenance in papyri may be taken as evidence for a presence of communities of an eastern, and possibly Iranian, origin inside Egypt.

\section{$1 \quad$ Migration during the Abbasid Caliphate}

The subject of migration in the pre-modern Islamic lands seems understudied and has only recently gained attention as an analytical concept. This is of course a response to the fact that the present age has become a world of migration and scholars themselves have turned into a society of migrants more than ever before. Prior to this, the phenomenon has not found much interest, nor has the word migration itself appeared in titles of older literature. ${ }^{8}$

While the Arab conquests of the $7^{\text {th }}$ and 8 th centuries had been a movement of Arabian tribes from their core regions on the Arabian Peninsula and the Fertile Crescent into Asia and North Africa, the 9th century witnessed a swing back of easterners to the west. Notably a military elite of Turkish origin made its way to western lands of the caliphate and took leading military and political positions there, including Syria and Egypt. ${ }^{9}$ At about the same time, Iranian-born administrators followed the trend and settled in Syria and Egypt. This happened, partly at least, in the wake of a political collapse of central government in Iraq especially during the 86os A.D. anarchy of Samarra that brought

7 The search for names is not without pitfalls: Karabacek, Papyrus Erzherzog Rainer. Führer durch die Ausstellung, p. 182 had read in a Vienna papyrus now published as P.RagibPressoir = Chrest.Khoury I 65 (PERF 698) a Persian name Shahrzār, but Rāgib, "Contrat d'affermage", and after him Khoury, Chrestomathie, p. 121 have convincingly corrected the reading to the non-Persian name Nimrān instead. For the westernmost extent of Persian migrations in the Islamic world, see now Dold-Ghadar, Pers-Andalus.

8 Few possible exceptions are Ashtor, "Mouvement migratoire"; Berger, "Medieval Era Migrations"; Lapidus, "Evolution of Muslim Urban Society"; idem, Islamic Societies; Naqvi, "Islam and Migration"; Netton, Golden Roads.

9 Berger, "Medieval Era Migrations", p. 2257 speaks of "migrant soldiers". See also the chapter by Lutz Berger in this volume. 
occupational insecurity and physical turmoil for many. ${ }^{10}$ From narrative sources we learn that, once in Egypt, they occupied central posts of administration there. ${ }^{11}$ Families of specialists such as the al-Mādharā'ì, the Ibn Bistam, the Banū Māhujīr and the Banū al-Furāt families managed to keep their influence on the local society in Egypt for generations. ${ }^{12}$ The long-term consequences of this trend found their way into Islamicate collective memory that holds that culture comes from the east, and administrators have to be of Persian origin.

Arabic literary sources, such as chronicles and collections of biographies but also administrative manuals, mention the presence of considerable numbers of "Persian" administrators already in 9th century Egypt. ${ }^{13}$ They also mention theologians and other intellectuals who came to Egypt as entourage of high administrative officials. ${ }^{14}$ From slightly later documents from the Cairo Genizah is known that high military men also brought to Egypt their entourage of courtesans and counsellors and that the latter took high posts in the administration of Egypt themselves. The new elites attracted still others in the hope for money and employment, and literary sources mention more common entourage, such as workers and domestics, who came to Egypt as well. ${ }^{15}$

We are not informed, however, about numbers or circumstances of the latter phenomenon, and whether they brought their own families and peers along. In addition, the question is whether the more common immigrants

$10 \quad$ Ashtor, "Mouvement migratoire", p. 194; Brett, "Egypt", p. 567.

11 The heads of the Umayyad chancery of Egypt were of Mesopotamian background, e.g. the cases of Ibn Abdkan and Isḥāq b. Nuṣayr (cf. for both Hassan, "Les Tulunides", pp. 280283). The important 9th century chronicler of Egypt, Ibn ad-Dāya, was of Mesopotamian background as well; cf. Hassan, Les Tulunides, p. 11, citing Guest, "Relations Between Persia and Egypt", pp. 170-171.

12 The al-Mādharāī family is attested in the papyrus CPR III 184 = P.Cair.Arab. 33. Among the families the Banū al-Furāt eventually became the most influential one in Egypt, see Ashtor, "Mouvement migratoire", pp. 190-191; Brett, "Egypt", p. 567. About the Mādharā̄ì and Banū Māhujīr families see Hassan, Les Tulunides, pp. 284-287 and Gottschalk, "Mādarā’iyyūn", passim.

13 The pioneer study is Guest, "Relations Between Persia and Egypt", which has been completed by Yarshater, "Persian Presence". Both are monumental compilations of all information obtainable from literary sources about Persian migrants to Egypt during the $9^{\text {th }}$ century but do not sufficiently take into consideration the actual social processes that stood behind their migration. The important recent study by Berger, "Muslim Era Migrations", on the other hand, provides an abundance of details about Arab and Turkic military migration and the role of slavery during the 8 th and 9 th centuries but passes over the migration of civil administrators, which shows very well the lack of sources scholars have to face when working about this subject.

14 Ashtor, "Mouvement migratoire", p. 192.

15 Ashtor, "Mouvement migratoire", p. 190. 
stayed in urban centres like Fustat or Alexandria or settled in villages as well, and how the local population reacted to newcomers. Arabic literary sources focus on the provincial centre of al-Fustat, however, and remain silent on the situation outside the capital. They follow an elite-based view and confine a majority of examples to higher levels of society. In addition, they depict events in an episodic manner, and it is difficult to say how representative the information is for the general situation. Documentary sources, on the other hand, are rare. The enormous potential of an archaeology of early Islam is still in its beginnings. ${ }^{16}$ The important Judaeo-Arabic documents on paper from the Cairo Genizah archive, on the other hand, had not been produced before the 1oth century and thus tend to be too late for the present purpose. ${ }^{17}$ Arabic papyri from 9th century Egypt, however, have a special value for tracing migration flows, since they have been found outside urban centres and from among less high-ranking milieus of society.

Arabic papyri from 9th century Egypt in fact feature inventions that had come into use in more eastern parts of the caliphal empire already about a century earlier. These concerned a general change from papyrus to paper as support of writing; ${ }^{18}$ the establishment of a script that was significantly more cursive than previous forms of writing, ${ }^{19}$ formulaic changes in documents; ${ }^{20}$ but also the introduction of Arabic numeral letters and a specific Persian calendar. ${ }^{21}$ It is of course possible that documents from Egypt followed a general trend of their time; but one cannot rule out the possibility that the new features were introduced by clerks of eastern origin working in Egyptian chanceries.

16 Cf. Guérin/Al-Na'imi, “Territory and Settlement Patterns" with exemplary research about settlement patterns in 9th century Qatar.

17 Ashtor, "Mouvement migratoire", who has made use of biographical collections and documents from the Cairo Geniza alike. Main findings are repeated in Ashtor, Social and Economic History, pp. 149 and 170.

18 Paper was a Chinese invention that found its way first into eastern Muslim lands in the mid-8th century but came into use in more western lands such as Syria and Egypt not before the 9 th and 1oth centuries. See Youssef-Grob, "Earliest Paper Documents" about the oldest Arabic documents on paper from Egypt.

19 Paragrapher Khan, Arabic Documents, pp. 28-29 with examples of Arabic documents from 8th century Khurasan.

20 Reinfandt, "Empireness", p. 286. An example of the new formulary in the papyri is CPR XXI $74=$ PERF 884 .

21 Early attestations of Arabic numeral letters in the documents are CPR XXII 15; P.Prag. Arab. Beilage II = P.World p. 136; P. Vind.inv. A.P. 1255 = PERF 830 (unpublished); P. Vind. inv. A.Ch. 11 = PERF 927 (unpublished). For the introduction and use of Arabic numeral letters see Abbott, "Arabic Numerals"; Irani, "Arabic Numeral Forms"; Kunitzsch, "Transmission of Hindu-Arabic Numerals"; Levi della Vida, "Appunti e questi". 


\section{Textual Evidence for a Presence of Transregional Elites in 9th Century Egypt}

Arabic papyri provide evidence in three different ways. First, the appearance of Persian or Turkish personal names in the documents allows locating a factual presence of individuals in the region and may give some information about their professional occupation and social role. Secondly, the use of administrative terminology different from local habits in the papyri may reflect the presence of newcomers in middle and lower levels of administration and in more peripheral parts of Egypt. Thirdly, the mentioning of luxury goods with a specific non-Egyptian background in the papyri may testify some cultural impact from outside.

\subsection{Onomastics}

Personal names of Persian origin begin to appear in Egyptian papyri during the earlier 9th century. Members of the financial administration but also traders and administrators of agricultural domains in rural centres like the Faiyum, al-Bahnasā (Oxyrhynchus), and al-Ushmūnayn (Hermopolis) have apparently Persian names, such as Salmān and Rastān. ${ }^{22}$ Others were marking their origin from more eastern parts of the caliphal empire by a nisba (geographical designation) in their name such as al-khurasānī ("the one from al-Khurāsān"). ${ }^{23}$ Suggestive is also the use of Persian personal names in a writing exercise from the gth century. ${ }^{24}$ From the early 10 th century at the latest is attested a permanent settlement of persons with Persian names who seem to have had become members of the local Egyptian society. ${ }^{25}$ Similarly, persons with Turkic names

22 Traders with possible Persian names are mentioned in papyri from 3 rd/9th century Faiyum, al-Bahnasā, and al-Ushmūnayn: P.Marchands v/1 1 (Salmān); 2 (Rastān or Raysān); 7 (Salmān ibn Dāwūd); 11 (Salmān); 12 (Rastān or Raysān); P.Cair.Arab. 94 (Aḥmad ibn Salmān); IV 234 (Salmān ibn al-Mufaḍḍal); 243 (Salmān); v 383 (Ḥamūd ibn Salmān).

23 Cf. the example of an Abū l-Ḥasan al-Khurasānī and his brother Abū al-Layth al-Khurasānī, both mentioned in a papyrus from 3 rd/9th century Faiyum (P.Berl.Arab. I 15r). I am grateful to Petra Sijpesteijn (Leiden) for having drawn my attention to this particular document.

24 P.Vind.inv. A.P. 3004 = PERF 786 (unpublished). Josef von Karabacek for his part even suggested a specific Persianized grammatical construction in another Arabic papyrus: P.Vind.inv. A.P. $3800=$ PERF 785 (unpublished).

25 One of them was the tax-official Yālawayh who was working in the southern Egyptian provincial centre of al-Ushmūnayn during the year 291/903-04 (P.GrohmannUrkunden 12). A similar case seems to have been another tax-official, a certain Abū l-Faḍl Hibatallāh b. al-Muhtadī billāh, who was in office in the Egyptian periphery during 297/909-10 (P.GrohmannGrundsteuerquittung). From 293/905-06 is mentioned a certain Ismā̄il (or Yishmāeēl) ibn Fath as tax-official in the Faiyum, his patronym perhaps pointing to a 
appear in Egyptian papyri as early as the year $172-73 / 789 .{ }^{26}$ The first Turkish governor of Egypt, al-Abbās ibn 'Abdallāh, is mentioned in a papyrus from $242 / 856 .{ }^{27}$ Other individuals with a Turkic background, however, are attested in 9th century documents as well. ${ }^{28}$ There are also attestations to people from southern Mesopotamia in the papyri. ${ }^{29}$

Moreover, there are other indicators used in combination with personal names that may have marked an origin from outside Egypt. This is the case with epithets such as nașrānī, 'ajamī, or färisī. The epithet an-nașrānī ("the Christian") was uncommon among gth century Christian Egyptians who would have preferred an-nabațī ("the indigene") instead, while a Christian from Syria and Anatolia would have been called ar-rūmi ("the one from Byzantium"). The epithet an-nașrānī, on the other hand, may have been an indicator for a more eastern origin of a person..$^{30}$ The name affix al-ajami ("the non-Arab")

Persian or Turkish father, whereas the personal name Yishmāeèl (as may be read from the document) would suggest his Jewish background (CPR XXI 74).

26 A certain Bakīsh (or Tikīsh/Tégish) freedman of Ṭulayb ibn Abī Ṣāiim is mentioned who sold an amount of wheat for the price of one gold dinar to a woman named 'Aqīla bint Yūsuf (CPR XXVI 16 = PERF 617). Josef von Karabacek in his day considered it the earliest attestation to a person of Turkish descent in Arabic papyri from Egypt (Karabacek, Papyrus Erzherzog Rainer. Führer durch die Ausstellung, p. 159). The provenance of the papyrus is unclear but has most probably been found in the Faiyum, Ihnās (Heracleopolis), or al-Ushmānayn (Hermopolis). The mentioning of the first Turkish governor of Egypt, al-'Abbās ibn 'Abdallāh, is much later, on the other hand: P.GrohmannAperçu p. $27=$ P.World p. 119 (PERF 763) from 242/856.

27 P.GrohmannAperçu p. 27 = P.World p. 119.

28 P.Vind.inv. A.P. 9014 = PERF 855 unpublished (Bughā); CPR XXI 77 with emendations in Diem, "Philologisches", p. 99 (Aḥmad ibn Abī al-Lawḥ ibn Sīmā); P.Prag.Arab. 40, Faiyum (Takin); P.Prag.Arab. Beilage I, al-Ushmūnayn (Sankar?). Both P.GrohmannUrkunden 2 from 328-33/939-44 and the unpublished P.Vind.inv. A.Ch. 7816 mention a Turkic ruler ('amìr) from the later Egyptian local Ikhshīdid dynasty (Abū l-Muẓaffar al-Ḥasan ibn Țuqaj/Ṭugh/Thogaj). The content of P.Harrauer 61 is dealing with agricultural domains in Egypt that were in the possession of a caliph's mother and a Turkish chief armourer; see Frantz-Murphy, "Record of Tax", p. 246.

29 P.Vind.inv. A.P. $8744 \mathrm{R}=$ PERF 671 unpublished is mentioning members of the family of the governor of Ahwāz possessing large estates in the Faiyum but is ambiguous as to whether these family members actually resided inside Egypt. CPR XVI 19 has a female slave of apparently eastern European, or Slavic, origin (khädim șaqlabiyya) from the market in al-Fustat.

3o Cf. the example of Mūsā an-Nașrānī who is mentioned in an Egyptian papyrus from as early as the 2nd/8th century and in the context of ships belonging to long-distance traders (P.Khalili I 7 = P.Khalili II 4 with unclear provenance). Later evidence is Qïriqah(?) ibn Thiyudur ibn Samawīl an-Nașrānī (P.AbbottMarriageContracts 2 = Chrest.Khoury I 15, Aswan, 378/989); Isiṭōrās ibn Bīyisa at-Tinnīsī (i.e., from the city of Tinnīs in the Nile Delta) an-Nașrānī (P.Cair.Arab. 68, al-Ushmūnayn, 459/1067); Abū as-Sarī ibn Hiliya ibn 
is commonly used for Iranians in Arabic literary sources but is rarely found in papyri and in the latter case always designating a Coptic or Nubian background. ${ }^{31}$ The epithet al-färisī ("the one from Persian"), on the other hand, is conspicuously absent in papyri. ${ }^{32}$ Likewise absent in the papyri are name affixes designating an origin from regions or large cities in the eastern lands of Islam, such as al-Farghānī or al-Wāsițī, that appear in Arabic literary sources. ${ }^{33}$ Relatively common in 9th century papyri, however, are Persian names with the specific ending -wayh (as is the case in Sibawayh or Dāshway). The majority seems to have belonged to higher officials residing in the provincial centre of al-Fustat, but at least one example of a simple taxpayer having such a name is preserved from al-Ushmūnayn. ${ }^{34}$ Although small in number, the evidence points to a presence, and perhaps even settlement, of Iranians in Egypt outside al-Fustat already from the earlier gth century on.

\subsection{Administrative Terminology}

In the course of the 9th century, Arabic papyri display a reform in the use of administrative terminology. Older terms were making way for equivalents from the Persian language in the technical language of administration in Egypt. An example is the Persian word daftar ("register, account book") as a substitute for the older equivalents tabl and sijill, which were Arabized loan words from the Greek. ${ }^{35}$ Another example is the Persian word dihqān ("village headman") in preference to the older māzūt or șāhib al-qarya. ${ }^{36}$

Rafrafìl an-Nașrānī (P.Cair.Arab. 54 = P.World p. 203, Faiyum, 448/1056); Sāra bint Qulta al-qazzāz ("the silk-mercer") an-Nașrāniyya (P.Cair.Arab. 69, al-Ushmūnayn, 459/106667); Yuhannis ibn Buqtur ibn Yuhannis an-Nașrānī (P.AbbottMarriageContracts 1 = Chrest. Khoury I 10, Aswan, 336/948); Qulta ibn Kayl ibn Jurayj an-Nașrānī al-qazzāz (P.Cair.Arab. 65, al-Ushmūnayn, 441/1050).

31 P.RagibPressoir = Chrest.Khoury I 65; P.RagibColombine; P.Terminkauf 1; P.Marchands I 7; 8; P.David-WeillContrat; P.Cair.Arab. 89; 96 = P.World p. 208 = Chrest.Khoury I 61; P.Cair. Arab. 97; 369 . For the use of 'ajam to denote either slaves from Nubia or the Coptic language, cf. P.Vente 6; P.Frantz-MurphyComparison I 1; 2; P.FahmiTaaqud 9. See also Cooperson, "Arabs and Iranians" about the often misleading meaning of this epithet.

32 Evidence for a use of al-fārisī denoting administrators of a Persian background in literary sources is given in Ashtor, "Mouvement migratoire", p. 189.

33 Attestations from literary sources for officials in Egypt with such names are collected in Ashtor, "Mouvement migratoire", p. 189.

34 P.Cair.Arab. 173 (Khumārawayh ibn Ahmad ibn Ṭūlūn); P.Cair.Arab. 247 (Tamīm ibn Jubbawayh/Habbawayh/Ḥannawayh); P.GrohmannUrkunden 12 clay seal, al-Ushmūnayn (Yalawayh); P.Prag.Arab. Beilage 1, al-Ushmūnayn ('...swayh).

35 Frantz-Murphy, "Corpus and Context", p. 222. For attestations in the papyri cf. P.Cair.Arab. 285; 309; 419; P.GrohmannUrkunden 9.

36 Lev, “Coptic Rebellions", p. $33^{2}$. 
The substitution of an established terminology by new words from the Persian language is also evident in the case of the word for "tax-collector". This was an official central to the demands of caliphal administration but in the same time very close to the local tax-paying population. In papyri from the 9 th century, the older term qusțăl is gradually substituted by the term jahbadh. ${ }^{37}$

37 The following papyri mention qustâls: P.GrohmannQorra-Brief (Faiyum, 9o/709, Qusta/ Kostas); P.World p. 130 = P.DiemAphrodito p. 261 (Kawm Ishqawh, 91/710, Buțrus/Petros Jirja/Georgios); P.Cair.Arab. 285 (2nd-3rd/8th-9th century, Ibīmak/Abīmak/Epimak); P.GrohmannUrkunden 8 (al-Ushmūnayn, 223/838, Ishāa/Isaak ibn Sim‘ūn/Shimon); P.Steuerquittungen 4 (al-Ushmūnayn, 227/841-42, [Ibrāh?]īm); P.Cair.Arab. 181 with emendations in Diem, "Philologisches", pp. 62-63 (al-Ushmūnayn, 233/847-48, Mīnā/ Menas ibn Ibrāhīm); CPR XXI 41 with emendations in Diem, "Philologisches", p. 76 (al-Ushmūnayn, 224/839, Mīnā/Menas [ibn Ibrāhīm?]); CPR XXI 42 with emendations in Diem, "Philologisches",pp. 76-77 (al-Ushmūnayn, 225/840, Mīnā/Menas [ibn Ibrāhīm?]); P.Cair.Arab. 261 (al-Ushmūnayn?, 3rd/9th century, Mīnā/Menas [ibn Ibrāhīm?]); P.GrohmannUrkunden 13 (al-Ushmūnayn, 241/855, '̄̄sā ibn 'Alī); P.Philad.Arab. 11 (255/ 868-69, 'Īsā ibn 'Alī); P.GrohmannProbleme 11 (244/858-59, Qūrīl/Kyrillos ibn 'Īsā); P.GrohmannProbleme 16 (248/862, Qūrì/Kyrillos [ibn 'Īsā?]); P.GrohmannProbleme 11 (244/858-59, Ibrāhīm ibn Mīnā/Menas); P.Cair.Arab. 198 (246/86o, Dāwūd); P.Cair.Arab. 184 (249/863-64, N.N. ibn Apaheu); CPR XXI 55 (248/862) and CPR XXI 57 (251/865) and P.Steuerquittungen $5\left(25^{2} / 866\right)$ and CPR XXI $5^{8}(253 / 867)$ and CPR XXI $59(253 / 867)$ and CPR XXI 65 with emendations in Diem, "Philologisches", pp. 91-93 (264/878) and P.GrohmannUrkunden 14 (265/878) and P.Vind.inv. A.P. 3498 unpublished (270/883-84) (all from al-Ushmūnayn; Andūna/Antonius ibn Qūrìl, perhaps identical with the tax official Andūna mentioned in CPR XVI 6 from the 3 rd/9th century); CPR XXI $56=$ P.Berl. Arab. I 6 (al-Ushmūnayn, 259/872-73, Muhammad ibn Ja'far); P.Cair.Arab. 185 (261/875) and P.Vind.inv. A.P. 3498 unpublished (270/883-84) and P.Vind.inv. A.P. 11234 (PERF 676) unpublished (3rd/gth century) (all from al-Ushmūnayn; Baqām/Pachom ibn Buqțur/ Viktor, probably identical with the qusțāl Baqām mentioned in P.Cair.Arab. 421 from al-Ushmūnayn, 3rd/9th century and in CPR XVI 21 from the $3 \mathrm{rd} / 9$ th century and perhaps the brother of the qusțāl Iștifān/Stephanos ibn Buqțur/Viktor mentioned in P.Prag.Arab. 14 from 261/874-75); P.Cair.Arab. 196 (Faiyum, 262/875, 'Alī ibn Sulaymān); P.Philad. Arab. 12 (al-Ushmūnayn, 275/889, Ḍimād b. Ziyād); P.GrohmannUrkunden 11 (287/90o, Yuhannis/Ioannes ibn Kayl/Chael); P.GrohmannUrkunden 12 (al-Ushmūnayn, 291/90304, Shanūda/Senouthios); P.Giss.Arab. 2 (Madinat al-Fayyūm, 3rd/9th century, Bisbinūda/ Pespnute); P.Hamb.Arab. II 12 (al-Bahnasā?, 3rd/9th century, Ahmmad, probably identical with the qustāl Ahmad ibn Jarīr in P.Cair.Arab. 277 from the 3 rd/9th century); CPR XVI 19 (3rd/9th century, Ya'qūb); P.Prag.Arab. 26 (Mūsā ibn Ayyūb). -- Other papyri mention the jahbadh: P.GrohmannProbleme 14 (249/863, Sahl ibn Dāwūd); P.Harrauer 61 (Faiyum, 253/867, Aḥmad ibn 'Īsā ibn Manșūr; Isrā̄̄il/Israel ibn Mūsā/Moses; Kayl/ Chael; Sulaymān/Salomo ibn Zakariyā'/Zacharias); P.Steuerquittungen 6 (Faiyum, 257/870-71, Abū Buqțur/Viktor ibn Thiyudūr/Theodoros); CPR XXI 70 with emendations in Diem, "Philologisches", pp. 94-95 (Faiyum, 286/899-90o, Sawirus/Severos ibn Jirja/Jurayj/Georgios); P.Cair.Arab. 189 (287/90o, Apaheu ibn Mā‘a); P.Ryl.Arab. II 3 (al-Ushmūnayn?, 292?/904-05, Menas/Minyā/Mīnā ibn Shanūda/Senouthios); P.Cair. Arab. 190 (293/9o6, Menas/Minyā/Mīnā ibn Shanūda/Senouthios); P.DietrichTopkapi 2 


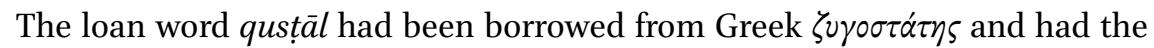
meaning of "tax-collector". ${ }^{38}$ The word jahbadh, on the other hand, was of Persian origin and had the meaning of "paymaster". ${ }^{39}$ Arabic administrative manuals and papyri give the impression that both terms were used indiscriminately for the same field of duties. ${ }^{40}$ The emergence of the Persian term jahbadh in

(al-Ushmūnayn, 294/906-07, Menas/Minyā/Mīnā ibn Shanūda/Senouthios, apparently identical with the jahbadh Mīnā ibn Shanūda mentioned in P.Vind.inv. A.P. 12916 (PERF 893) unpublished from 301/913-14); P.Cair.Arab. 190 (293/906, Sawīrus ibn Zakariyyā); P.Ryl.Arab. II 2 (al-Ushmūnayn?, 295/907-08, Niqla/Nicholas ibn Andūna/Antonios); P.Cair.Arab. 278 (al-Ushmūnayn, 3rd/9th century, Ișțiān/Stephanos ibn Jurayj/Georgios); P.Cair.Arab. 43 (al-Ushmūnayn?, 306/918, Ḥamdān ibn 'Umar ibn Muhājir); P.Cair. Arab. 193 (314/926, Yuḥannis ibn Mīnā); P.Cair.Arab. 19 (318/930) and P.Cair.Arab. VII 446 (319/931, Marqūra/Merkure ibn Mīnā, probably identical with the jahbadh Abū Jamīl Marqūra ibn Mīnā mentioned in P.Cair.Arab. 199 from 347/958); P.Steuerquittungen 28 (Faiyum or al-Ushmūnayn, 311-99/923-1008, Jurayj ibn Marqūra); P.Cair.Arab. 194 (al-Ushmūnayn, 405/1015, Baqām/Pachom ibn Shanūda); P.KarabacekPapier 5 with emendations in Diem, "Philologisches", p. 58 (427/1036); P.Prag.Arab. 47 (al-Ushmūnayn, 440/1048-49) and P.Prag.Arab. 48 (Faiyum, 447/1055, Abū al-Alā'); P.Prag.Arab. 48 (Faiyum, 447/1055, Yāsir); P.Prag.Arab. 48 (Faiyum, 447/1055) and P.Prag.Arab. 49 (al-Ushmūnayn, 449/1057, Jirja ibn Isițūrus); P.Prag.Arab. 48 (Faiyum, 447/1055, Marqūra); P.Prag.Arab. 49 (al-Ushmūnayn, 449/1057, Șubḥ ibn 'Abdalmasịn); P.Prag.Arab. 49 (al-Ushmūnayn, 449/1057, Ṣālih ibn 'Imrān); P.Ryl.inv. Arabic Add. no. 351 unpublished (al-Ushmūnayn, 292/904) and P.Cair.Arab. 290 (3rd/9th century) and P.Hamb.Arab. II 14 (Edfu?, 3rd/9th century) and P.Cair.Arab. 280 (342/953-54) and P.Ryl.Arab. I, II 2.

38 The same term also appears in variants, such as qustāl, jusțāl, qusțār, as for example the unnamed jusțāl in P.BeckerNPAF 3 = P.Cair.Arab. 149 (Kawm Ishqawh, 90-96/709-14). For

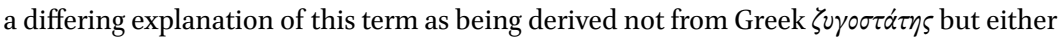

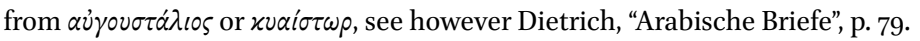

39 Frantz-Murphy, "Arabic Agricultural Leases", pp. 121-123, and idem, "Corpus and Context", p. 222 is translating qusțāl as "receiver" and jahbadh as "cashier". For the meaning of jahbadh see Dietrich, Arabische Briefe, p. 87 with reference to research literature. According to Dietrich, Arabische Briefe, p. 66 and Grohmann, "Beamtenstab", p. 132 jahbadhs in the 9 th century mostly had a Christian background.

40 Under the Abbasid caliphate, the qustäl was part of the office of the financial director ('âmil) of an administrative district (küra) and appears in the documents as an issuer of tax-quittances; see Dietrich, Arabische Briefe, p. 8o. Morimoto, Fiscal Administration of Egypt, pp. 214-215 and 243 understands both terms as being synonymous, the Persian term jahbadh having emerged during the earlier Abbasid era and gradually coming to supersede the term qusțäl. Grohmann, "Verwaltungstermini", p. 279 remarks that the administrative manual of Ibn Mammātī (6th/12th century) describes the tasks of the jahbadh as identical to those of the qusțäl. Dietrich, Arabische Briefe, p. 66, on the other hand, does not commit himself to whether the term jahbadh entirely substituted the term qusțāl in the documents. According to Grohmann, "Beamtenstab", 127 and 132 qusțāls took the tax-money that had been collected from (Christian) local heads of districts (pagarchs), and weighed and rated them. Similarly, they collected the taxes paid in grain and forwarded them to the state granaries. In return, they were responsible for the assignment of tax payments to administrative districts. Insofar Grohmann understood the qusțāls, at 
Arabic papyri from the 9th century may have been a consequence of an Iranisation of the administration of Egypt in this era, be it either in terms of documents or real persons.

Arabic literary sources explicitly state that "ethnic Persians had come to dominate Egypt's agrarian fiscal administration by the mid-9th century". ${ }^{41}$ Persian administrators of this kind were primarily holding high-ranking positions in the central administration in al-Fustat, to be sure, but the appearance of the term jahbadh in papyri may reveal their presence in the Egyptian periphery as well. According to the evidence in datable documents, there was a temporary parallel use of both terms during the second half of the 9th century, the latest attestation of the older term qustāal being from 919 A.D. and the earliest attestation of the younger term jahbadh being from 863 A.D. ${ }^{42}$ It seems as if a new generation of specialists entered the middle-level administration in the Egyptian province that had until then been reserved for elites of a more local background.

From the documents, we get the impression that jahbadhs first appeared in the Faiyum and only afterwards made an advance to the more southern district city of al-Ushmūnayn (Hermopolis). ${ }^{43}$ Such a gradual spread from north to south would have been no surprise but indeed to be expected. More surprising is the fact that jahbadhs, as can be concluded from the documents, were by their majority Coptic Christians, as had been the qusțāls before. ${ }^{44}$ There seems to have been a continuity of Christians on the middle level of administration

least for the Umayyad period (661-750), as being superior to the local pagarchs, while Foss, "Egypt under Mu'āwiya", p. 12 maintains that the qusțāls were subordinate to the pagarchs. There is reason, however, to follow the latter opinion on the basis of P.BeckerNPAF 3 = P.Cair.Arab. 149 and P.World p. 130 = P.DiemAphrodito p. 261. For an explanation of the meaning of jahbadh on the basis of Mesopotamian sources, see Løkkegaard, Islamic Taxation, pp. 158-16o; Cahen, "Quelques problèmes économiques".

41 Frantz-Murphy, "Corpus and Context", p. 222 with relevant references.

42 The latest attestation of a qustāl is P.Vind.inv. A.P. 13986 (PERF 896) unpublished (306/918-19); see Grohmann, "Verwaltungstermini", p. 278. The earliest evidence for jahbadh is P.GrohmannProbleme 14 (249/863).

43 G. Frantz-Murphy was the first to mention the fact that jahbadhs are only attested in documents from al-Ushmūnayn and the Faiyum. Cf. Frantz-Murphy, "Record of Tax", p. 247.

44 Examples for qusțāls with a Muslim background are 'Īsā ibn 'Alī in al-Ushmūnayn in 855 and 869; Muhammad ibn Ja'far in al-Ushmūnayn in 872; 'Alī ibn Sulaymān in the Faiyum in 875; Ḍimād b. Ziyād in al-Ushmūnayn in 889; Ahmad ibn Jarīr in al-Bahnasā; moreover a certain Ya'qūb and a Mūsā ibn Ayyūb, both with unclear provenance and time. Examples for jahbadhs with a Muslim background are Sahl ibn Dāwūd in 863; Aḥmad ibn 'Īsā ibn Manșūr in the Faiyum in 867; Ḥamdān ibn 'Umar ibn Muhājir in al-Ushmūnayn in 918; Abū al-'Alā' in both al-Ushmūnayn in 1049 and the Faiyum in 1055; Yāsir in the Faiyum in 1055; Șubḥ ibn 'Abdalmasīḥ and Șâliḥ ibn 'Imrān in al-Ushmūnayn in 1057. The fact that 
during the 9th century. This is all the more remarkable since the caliphal empire had had reorganised its provincial administration a century earlier by a replacement of non-Muslim local elites by Arab Muslims in Egypt. It seems that during the 9th century, the process of Arabisation was reversed and the personnel on the middle level of administration adapted by the needs of a new Iranian-born elite in Egypt in quest of reliable allies among the local population.

\subsection{Luxury Goods}

There are a few attestations of luxury textiles from eastern lands of Islam in 9th century Arabic papyri from Egypt. All are from gth century Faiyum. ${ }^{45}$ As can be concluded from the names used, these textiles were of a specific Persian style. They were too prestigious and high-cost to serve a rural market in Egypt but presumably met the needs of an Iranian population living and working in Egypt. Especially when based outside the provincial capital of al-Fustat these specialists of administration and their entourage were feeling culturally alien and at the same time may have been in demand of symbols of a social distinction from a more established local population.

The same applies to food products. While Egyptian apples were proverbial for their low quality, those from Syria and Iranian lands were purportedly sweet and juicy. ${ }^{46}$ Apples of a distinguished quality appear in Egyptian papyri

both qusțāls and jahbadhs were by their majority Christians has already been suggested by Dietrich, Arabische Briefe, p. 66 and Grohmann, "Beamtenstab", p. 132.

45 P.Vind.inv. A.P. 2112; 5583; 5584 (all unpublished). Another unpublished papyrus, P.Vind. inv. A.P. 15045 (PERF 642) mentions the arrival of 40 trading ships from Syrian Antiochia bringing different kinds of consumer goods to Egypt. Both P.GrohmannProbleme $3 \mathrm{r}$ and P.Vind.inv. A.P. $11416 \mathrm{v}$ (unpublished) mention perfume and drinking glasses of a possible non-Egyptian production. For other products with a possible luxury background see P.GrohmannWirtsch. 16; P.Vind.inv. A.P. 7718r (unpublished). Another unpublished papyrus, P.Vind.inv. A.Ch. 3637 (PERF 975) from the 4th/1oth century, contains Persian designations such as jafneh (platter, dish) and täbüt (coffin, wooden box). P.Vind.inv. A.Ch. 7333 (PERF 1190) from the 4th-5th/10th-11th century (unpublished) contains products made of silk and perhaps of a Persian background.

46 See both Dietrich, "Tuffāh", p. 587 and Müller-Wodarg, "Landwirtschaft", p. 71 for the superior quality of eastern apples. The comprehensive study by Watson, Agricultural Innovation, on the other hand does not mention apples at all. The Arabic world for apple (tuffāh) is derived from Hebrew tappūh and Old Egyptian dph ; see Hehn, Kulturpflanzen, p. 628. Felix Dahn's popular novel Ein Kampf um Rom (Leipzig 1877), here p. 44 is but one example of how the trope of "Persian apples" has eventually found its way into 19th century Professorenliteratur. 
from the 9 th century. ${ }^{47}$ They did not replace the local products but were traded for a specific clientele that had an interest in social distinction and that had the material means to consume luxury products. Both food and clothing had an eye-catching effect on the surrounding society and served an ostensive marker of exclusivity and distance. The more sophisticated the distinction, the stronger it was an indicator for social stratification and the presence of new elites. ${ }^{48}$ In the case under consideration an affinity of eastern, Iranian culture may have been put on display that served a social capital in an Egyptian environment outside of al-Fustat.

Horses (hișān; hağin $)$ and their breeding was also an important issue that begins to appear in papyri from 9th century Egypt. Turks and Khurāsānians fought on horseback, whereas the Egyptian military (maghäriba) formed part of the infantry. ${ }^{49}$ Contingents of foot soldiers from Egypt belonged to the caliphal army and were as such committed to other regions of the empire, such as Iraq and the Ğazīra (northern Mesopotamia). ${ }^{50}$ In Caesarea, Jaffa, Ramla, and Yahweh-Yam a specific kind of Egyptian pottery has been found that was unsuitable as a container for transporting foodstuff or other goods but was in use for food preparation in a specific Egyptian way. ${ }^{51}$ These so-called Egyptian coarse ware basins (ECWB) give reason to the fact that foot soldiers from Egypt (maghäriba) had also permanently settled in Palestine. ${ }^{52}$ Such pottery may hint at a more permanent settlement of Egyptian wives, children and all kind of entourage as well as civilian merchants alongside Egyptian warriors in Palestine during the 9th century. ${ }^{53}$ While Egyptian soldiers settled in Palestine, Syria and Mesopotamia, "Iranians" and Turks on the other hand were sent to Egypt and permanently settled there from the earlier 9th century on. ${ }^{54}$ Their

47 P.Vind.inv. A.P. 1029; 8031 = PERF 805; 8992; 11186 = PERF 873 (all unpublished); P.Berl.inv. 15150; P.Cair.Arab. 427; P.Heid.Arab. II 55; P.Khalili I 17 = P.Khalili II 74; P.Marchands II 24; P.Prag.Arab. 78 .

48 Van der Veen, "When is Food a Luxury", p. 408. I am indebted to Hagit Nol (Hamburg) for having drawn my attention to this article.

49 Kennedy, Armies of the Caliphs, p. 126 with reference to the 9th century Arabic historian at-Tabarī (Ta'rikh ar-rusul wa-l-mulūk).

$5^{0}$ Kennedy, Armies of the Caliphs, p. 125.

51 Taxel/Fantalkin, "Egyptian Coarse Ware", p. 94. I am indebted to Hagit Nol (Hamburg) for having drawn my attention to this article.

52 Vroom, Medieval and Post-Medieval Ceramics, p. 74.

53 Taxel/Fantalkin, "Egyptian Coarse Ware", pp. 95-96 and ibid., n. 66 and 67.

54 Kennedy, Armies of the Caliphs, p. 126. Numbers were quite high: When the caliph sent troops to Egypt in 214/829-30 to quell a local tax revolt, he sent 4000 Turkish soldiers. On the other hand the caliphal army stationed in Samarra comprised a rather large contingent of Egyptians consisting of 2000 maghäriba (next to 5000 Turks and Ferghanians). Kennedy (ibid.) speculates that the men captured during these raids may well have been 
need of horses is documented by a group of eight deeds of sales of horses ( $h a$ ğin) edited by Youssef Ragheb and dated by him to the later 9 th century. ${ }^{55}$

Turkish personal names become more common in Egyptian papyri from the slightly later Umayyad period (868-905) ${ }^{56}$ From this evidence alone, it is not easy to conclude about their exact settlement in Egypt, but their presence in principle is a fact. Arabic literary sources mention that the Abbasid imperial centre in Samarra and Baghdad lost control over large areas in Syria, Palestine, Egypt and northern Iran after the civil war following the death of Harun arRashid (809-27). For their reconquest a new army was built that was made up of Turkish soldiers but contained also important contingents from the Iranian principalities of Transoxania. In this new army, there was no room for recruits from Iraq, the Ğazīra (northern Mesopotamia), Syria, Palestine, and the Arabian Peninsula. Except for the Egyptian foot soldiers (maghäriba), all the troops came from Iran or from beyond the borders of the Muslim world. ${ }^{57}$ It is understood that the caliphal army in Egypt was dominated by a strong Central Asian contingent as well.

Arabic literary sources draw a picture of a noteworthy migration of administrative personnel from eastern lands of Islam to Egypt during the 9th century. Egyptian documents on papyrus from a local production seem to corroborate the scenario, albeit based on a few indicators, namely personal names, administrative terms and the mentioning of specific goods. Iranians took key positions in the high administration of al-Fustat, but others settled in district centres such as the Faiyum or al-Ushmūnayn in Middle Egypt. They were either administrators of agricultural domains in the caliphal possession or traders, but in both cases they must have brought their families and peers along.

It remains unclear from the sources how the local population in Egypt reacted to the developments. One can also only guess about what held translocal families together over long distances and what were the sets of values shared among migrants and between newcomers and host societies. In addition, the role of space in migration is important and not least all the kinds of ambiguity

the maghäriba that are recorded in later years as fighting in the ranks of the caliphal army in other parts of the empire.

P.Vente 16-23, with purchasers having Turkish names such as Muḥammad ibn Bulghāq, 'Alī ibn Bulghāq. Cf. also Vanthieghem, "Maquignon", p. 289.

56 Rāgib, Actes de vente d'esclaves, p. 47.

57 Kennedy, Armies of the Caliphs, pp. 118-119. 
and in-betweenness that is connected to migration. It should be possible, however, to say something about the motives of migration and about the consequences of this trend in a larger imperial perspective. The matter is framed by two events on the macro-level of gth century history. One is the Abbasid reconquest of Egypt after the civil war between al-Amin and al-Ma'mūn during the 820s. The other one is the takeover of Egypt under Ahmad ibn Țūlūn half a century later. During this period, Egypt had an essential role for guaranteeing imperial coherence due to its resources and its strategic role as a link between North Africa and the eastern Mediterranean. ${ }^{58}$

The control of Egypt was not possible without a cooperation of local elites. It had, on the other hand, to be managed by agents loyal to the caliphal centre in Samarra and Baghdad as well. A new generation of administrators with an Iranian background met this demand, being a type of household officials devoid of local bonds but loyal to the imperial centre. First taking over high positions in al-Fustat as delegates of imperial control, they gradually gave way to a local elite (families) of landowners and office holders. These latter got a more and more aristocratic appearance similar to former non-Muslim (Coptic) local elites and therefore had to be filled up with new personnel from the caliphal household. The continuous arrival of new personnel prevented tendencies of a local self-awareness and the grip to power by local aristocracies of whatever ethnic groups. Still Aḥmad ibn Ṭūlūn, in his alleged move towards political independence from the caliphate, had to balance between the supra-regional interests of empire and the power of local notables and resources. The outcome was a "politics of deference". 59 In other words, his was a strategical option for compromise: all his local Egyptian management notwithstanding he remained a loyal governor of the caliph. Even his intent of moving the seat of the caliph from Samarra to Fustat was in the end a commitment to imperial legacy rather than pragmatic regionalism. ${ }^{60}$

Egyptian papyri also show that a first generation of Iranian-born administrative elites had arrived in Egypt already before the tumultuous 86os A.D. and others continued to do so long after. The migration affected host societies and was a key factor for provincial politics of the empire. The staffing of the financial administration of Egypt with experts from eastern lands took place at the same time when the civil administration was taken over by members of the Turkish military elite. In an effort to maintain the control over Egypt's agricultural revenues, the caliphal imperial centre appointed Iranians on key positions

$5^{8}$ See for political events Kennedy, "Egypt as a Province of the Caliphate"; Brett, "Egypt".

59 Gordon, "Politics of Deference", p. 229.

6o Gordon, "Politics of Deference", p. 244. 
both in the offices of al-Fustat and as overseers of caliphal estates in the countryside. The latter settled in large agricultural centres such as the Faiyum and al-Ushmūnayn, while the core-business of tax-collection on the ground level remained in the hand of Coptic Egyptians. These proved to be trustful allies, and the continuous Coptic tax-revolts of the 8th and early gth centuries now ended. ${ }^{61}$ The renewed social influence of Coptic elites found its expression in a renaissance of the Coptic language in Egyptian papyri from the gth and 1oth centuries. It was also the mainspring for a new local Egyptian identity that is reflected in the blooming genre of local histories from Egypt from the 9th century on. ${ }^{62}$

\section{Bibliography}

\section{Papyrological Sources}

Chrest.Khoury I = Khoury, R.G., Chrestomathie de papyrologie arabe. Documents relatifs à la vie privée, sociale et administrative dans les premiers siècles islamiques (Handbuch der Orientalistik. Ergänzungsband 2: Zweiter Halbband), Leiden/New York/ Cologne 1993 .

CPR III = Grohmann, A., Protokolle (Corpus Papyrorum Raineri, 3), Vienna 1924.

CPR XVI = Diem, W., Arabische Briefe aus dem 7.-10. Jahrhundert (Corpus Papyrorum Raineri, 16), Vienna 1993.

CPR XXI = Frantz-Murphy, G., Arabic Agricultural Leases and Tax Receipts from Egypt (Corpus Papyrorum Raineri, 21), Vienna 2001.

CPR XXII = Morelli, F., Documenti greci per la fiscalità e la amministrazione dell'Egitto arabo (Corpus Papyrorum Raineri, 22), Vienna 2001.

$61 \quad$ For alleged Coptic tax-revolts during the years A.D. 725, 739, 749, 752, 767, 783, 810, 819, 829, $83^{1-832}$ as well as the rebellion of Arabs in 866 A.D. see Lev, "Coptic Rebellions".

62 For local histories of 9th and 1oth century Egypt (especially Ibn 'Abdalhakam, but also al-Kindī, al-Balawī, and Ibn ad-Dāya) in their function as documents of a specific local consciousness, see Haarmann, "Regional Sentiment"; Sijpesteijn, "Building an Egyptian Identity"; and especially Kennedy, "Egypt as a Province". Local reactions on migrations from Iraq itself, in this case Turkish military slaves, find their expression also in al-Jāḥiz' famous Epistle of the Turks (9th century); see Hutchins, Nine Essays of al-Jahiz, pp. 175-218 (in English); Pellat, Arabische Geisteswelt, pp. 148-158 (in German). Another effect of the Persian immigration to more western lands of the caliphate was a local increase in Islamisation. This is at least evident from the case of Egypt where the immigration of Persian and Turkish elites (and their entourage) resulted in a growth of the Muslim sector of society; see Brett, "Egypt", p. 556. 
CPR XXVI = Thung, M.H., Arabische juristische Urkunden aus der Papyrussammlung der Österreichischen Nationalbibliothek (Corpus Papyrorum Raineri, 26), Munich/ Leipzig 2006.

P.AbbottMarriageContracts = Abbott, N., "Arabic Marriage Contracts Among Copts", Zeitschrift der Deutschen Morgenländischen Gesellschaft 95 (1941), 59-81.

P.BeckerNPAF = Becker, C.H., "Neue arabische Papyri des Aphroditofundes", Der Islam 2 (1911), 245-268.

P.Cair.Arab. = Grohmann, A., Arabic Papyri in the Egyptian Library, 6 vols., Cairo 1934-62.

P.David-WeillContrat = David-Weill, J., "Contrat de travail au pair. Papyrus Louvre 7348", in Études d'orientalisme dédiés à la mémoire de Lévi-Provencal, Leiden 1962, pp. 509-515.

P.DiemAphrodito = Diem, W., "Philologisches zu den arabischen Aphrodito-Papyri", Der Islam 61 (1984), 251-275.

P.DietrichTopkapi = Dietrich, A., "Die arabischen Papyri des Topkapı Sarayı-Museums in Istanbul”, Der Islam 33 (1958), 37-50.

P.FahmiTaaqud = Fahmī, 'A. [Fahmy, A.], "Watāàiq li-t-ta‘āqud min fağr al-Islām [Early Islamic contracts from Egypt]", Bulletin de l'Institut d'Egypte 54 (1972-1973), 1-58.

P.Frantz-MurphyComparison = Frantz-Murphy, G., "A Comparison of Arabic and Earlier Egyptian Contract Formularies", Journal of Near Eastern Studies 40 (1981) (= Arabic and Islamic Studies in Honor of Nabia Abbott, 2), 203-225; 355-356; 44 (1985), 99-114; 47 (1988), 105-112; 269-280; 48 (1989), 97-107.

P.Giss.Arab. = Grohmann, A., Die Arabischen Papyri aus der Giessener Universitätsbibliothek. Texte aus den Sammlungen Papyri bibliothecae universitatis Gissensis, Papyri Gissenses und Papyri Iandanae (Abhandlungen der Giessener Hochschulgesellschaft, 4.1 = Nachrichten der Giessener Hochschulgesellschaft, 28), Giessen 1960.

P.GrohmannAperçu = Grohmann, A., "Aperçu de papyrologie arabe", Études de papyrologie 1 (1932), 23-95.

P.GrohmannGrundsteuerquittung = Grohmann, A., "Eine arabische Grundsteuerquittung vom Jahre 297 H. (909/910 n.Chr.) aus dem Amtsbereich eines 'Abbasidenprinzen", in Mélanges Maspero, Cairo 1934, 9-13.

P.GrohmannProbleme = Grohmann, A., "Probleme der arabischen Papyrusforschung", Archiv Orientální 3 (1931), 381-394; 5 (1933), 273-283; 6 (1934), 125-149; 377-398.

P.GrohmannQorra-Brief = Grohmann, A., "Ein Qorra-Brief vom Jahre 90 H", in E.F. Weidner (ed.), Aus fünf Jahrtausenden morgenländischer Kultur. Festschrift Max Freiherr von Oppenheim, Berlin 1933 (repr. Archiv für Orientforschung: Beiband 1, Osnabrück 1977), pp. 37-40.

P.GrohmannUrkunden = Grohmann, A., "Einige bemerkenswerte Urkunden aus der Sammlung der Papyrus Erzherzog Rainer an der Nationalbibliothek zu Wien", Archiv Orientální 18 (1950), 80-119. 
P.GrohmannWirtsch = Grohmann, A., "Texte zur Wirtschaftsgeschichte Ägyptens in arabischer Zeit", Archív Orientální 7 (1935), 437-472.

P.Hamb.Arab. II = Dietrich, A., Arabische Briefe aus der Papyrussammlung der Hamburger Staats- und Universitäts-Bibliothek (Veröffentlichungen aus der Hamburger Staats- und Universitätsbibliothek, 5), Hamburg 1955.

P.Harrauer = Palme, B. (ed.), Wiener Papyri als Festgabe zum 6o. Geburtstag von Hermann Harrauer (P.Harrauer), Vienna 2001.

P.KarabacekPapier = Karabacek, J.v., "Das arabische Papier", Mitteilungen aus der Sammlung der Papyrus Erzherzog Rainer 2-3 (1887), 87-178.

P.Khalili I = Khan, G., Arabic Papyri. Selected Material from the Khalili Collection (Studies in the Khalili Collection, 1), Oxford 1992.

P.Khalili II = Khan, G., Bills, Letters and Deeds. Arabic Papyri of the 7 th to nth Centuries (The Nasser D. Khalili Collection of Islamic Art, 6), Oxford 1993.

P.Marchands = Rāgib, Y., Marchands d'étoffes du Fayyoum au IIIe/IXe siècle d'après leurs archives (actes et lettres), 4 vols. (Suppléments aux Annales Islamologiques: Cahiers 2; 5; 14; 16 = Publications de l'Institut Français d'Archéologie Orientale, 586; 631; 727; 768), Cairo 1982-1996.

P.Philad.Arab. = Levi della Vida, G., Arabic Papyri in the University Museum in Philadelphia (Pennsylvania) (Atti della Accademia Nazionale dei Lincei, $378=$ Memorie Classe di science morali, storiche e filologiche Serie viii, 25.1), Rome 1981.

P.Prag.Arab. = Grohmann, A., "Arabische Papyri aus der Sammlung Carl Wessely im Orientalischen Institute zu Prag”, Archív Orientální 10 (1938), 149-162; 11 (1940), 242289; 12 (1941), 1-112; 14 (1943), 161-260.

P.RagibColombine = Rāgib, Y., "Une vente à livrer de colombine en 320/932", Res Orientales 6 (1994) (= R. Curiel, R. Gyselen (eds.), Itinéraires d'Orient. Hommages à Claude Cahen. Textes réunies, Bures-sur-Yvette 1995), pp. 133-141.

P.RagibPressoir = Rāgib, Y., "Contrat d'affermage d'un pressoir à huile en 205/821", Studia Iranica 11 (1982) (= Mélanges offert à Raoul Curiel), 293-299.

P.Ryl.Arab. I = Margoliouth, D.S., Catalogue of Arabic Papyri in the John Rylands Library Manchester, Manchester 1933 .

P.Ryl.Arab. II = Smith, G.R./al-Moraekhi, M., The Arabic Papyri of the John Rylands University Library of Manchester (Bulletin of the John Rylands University Library of Manchester, 78.2), Manchester 1996.

P.Steuerquittungen = Diem, W., Arabische Steuerquittungen des 8. bis 11. Jahrhunderts aus der Heidelberger Papyrussammlung und anderen Sammlungen (Documenta Arabica Antiqua, 5), Wiesbaden 2008.

P.Terminkauf = Diem, W., Arabischer Terminkauf. EinBeitragzur Rechts- und Wirtschaftsgeschichte Ägyptens im 8. bis 14. Jahrhundert, Wiesbaden 2006.

P.Vente = Rāgib, Y., Actes de vente d'esclaves et d'animaux d'Egypte médiévale (Cahiers des Annales Islamologiques, 23), vol. 1, Paris 2002. 
P.World = Grohmann, A., From the World of Arabic Papyri, Cairo $195^{2}$.

PERF = Karabacek, J. von, Papyrus Erzherzog Rainer. Führer durch die Ausstellung, Vienna 1894 .

\section{Secondary Literature}

Abbott, N., "Arabic Numerals", Journal of the Royal Asiatic Society of Great Britain and Ireland 70 (1938), 277-280.

Ashtor, E., "Un mouvement migratoire au haut Moyen Age. Migrations de l'Irak vers les pays méditerranéens”, Annales. Histoire, Sciences Sociales 27 (1972), 185-214 (repr. in idem, The Medieval Near East. Social and Economic History (Variorum Series, 4), London 1978).

Ashtor, E., A Social and Economic History of the Near East in the Middle Ages, London 1976.

Berger, L., Art. "Muslim World, Medieval Era Migrations", in I. Ness et al. (eds.), The Encyclopedia of Global Human Migration. Vol. 4: Ind-Rem, Chichester 2013, pp. 2253-2261.

Brett, M., "Egypt", in C.F. Robinson (ed.), New Cambridge History of Islam. Vol. 1: The Formation of the Islamic World, Sixth to Eleventh Centuries, Cambridge 2011, pp. 541-580.

Cahen, C., Quelques problèmes économiques et fiscaux de l'Iraq buyide (Annales de l'Institut d'Études Orientales de la Faculté des Lettres d'Alger, 10), Algiers 1952.

Cooperson, M., “Arabs' and 'Iranians'. The Uses of Ethnicity in the Early Abbasid Period", in B. Sadeghi et al. (eds.), Islamic Cultures, Islamic Contexts. Essays in Honor of Professor Patricia Crone (Islamic History and Civilization, 114), Leiden/Boston 2015, pp. 364-387.

Crone, P., "The First-Century Concept of Hiğra”, Arabica 41 (1994), 352-387.

Crone, P., "Post-Colonialism in Tenth-Century Islam”, Der Islam 83 (2006), 2-38.

Diem, W., "Philologisches zu arabischen Steuerquittungen”, Wiener Zeitschrift für die Kunde des Morgenlandes 95 (2006), 55-111.

Dietrich, A., Arabische Briefe aus der Papyrussammlung der Hamburger Staats- und Universitäts-Bibliothek (Veröffentlichungen aus der Hamburger Staats- und Universitäts-Bibliothek, 5), Hamburg 1955.

Dietrich, A., Art. "Tuffāh", in P.J. Bearman et al. (eds.), The Encyclopaedia of Islam. New Edition. Vol. 10: T-U, Leiden 1999, p. $5^{87}$.

Dold-Ghadar, G., Pers-Andalus: iranische Kulturdenkmäler in "al-Andalus al-aqșā": Bewertung der Forschungsergebnisse für das 8.-12. Jahrhundert, Berlin 2016.

Donner, F.M., The Early Islamic Conquests, Princeton 1981.

Foss, C., "Egypt under Mu'āwiya. 1: Flavius Papas and Upper Egypt. 2: Middle Egypt, Fusțāt and Alexandria", Bulletin of the School of Oriental and African Studies 72 (2009), 1-24; 259-278. 
Frantz-Murphy, G., "Record of Tax from Imperial Estates in Ushmūnayn", in B. Palme, (ed.), Wiener Papyri als Festgabe zum 6o. Geburtstag von Hermann Harrauer (P. Harrauer), Vienna 2001, pp. 243-248.

Frantz-Murphy, G., Arabic Agricultural Leases and Tax Receipts from Egypt (Corpus Papyrorum Raineri, 21), Vienna 2001.

Frantz-Murphy, G., "The Corpus and Context. Agrarian Fiscal Administration and State Formation in Early Islamic Egypt, 717-1035 A.D./99-427 A.H”., in B. Palme (ed.), Akten des 23. Internationalen Papyrologen-Kongresses, Wien, 22.-28. Juli 2001 (Papyrologica Vindobonensia, 1), Vienna 2007, pp. 221-231.

Gordon, M.S., The Breaking of a Thousand Swords. A History of the Turkish Military of Samarra (A.H. 200-275/815-889 C.E.) (SUNY Series in Medieval Middle East History), Albany 2001.

Gordon, M.S., "Aḥmad ibn Ṭūlūn and the Politics of Deference", in B. Sadeghi et al. (eds.), Islamic Cultures, Islamic Contexts. Essays in Honor of Professor Patricia Crone (Islamic History and Civilization, 114), Leiden/Boston 2015, pp. 229-256.

Gottschalk, H.L., Die Mādarā’iyyūn. Ein Beitrag zur Geschichte Ägyptens unter dem Islam, Berlin/Leipzig 1931.

Gottschalk, H.L., Art. "Dīwān. ii. Egypt", in B. Lewis et al. (eds.), The Encyclopaedia of Islam. New Edition. Vol. 2: C-G, Leiden/London 1965, pp. 327-331.

Grohmann, A., "Griechische und lateinische Verwaltungstermini im arabischen Ägypten", Chronique d'Égypte 7 (1932), 275-284.

Grohmann, A., "Der Beamtenstab der arabischen Finanzverwaltung in Ägypten in früharabischer Zeit", in H. Braunert (ed.), Studien zur Papyrologie und Antiken Wirtschaftsgeschichte, Friedrich Oertel zum Achtzigsten Geburtstag gewidment, Bonn 1964, pp. 120-134.

Guérin, A./Al-Na'imi, F., “Territory and Settlement Patterns During the Abbasid Period (Ninth Century AD). The Village of Murwab (Qatar)", in Proceedings of the Seminar for Arabian Studies. Vol. 39, Papers from the Forty-Second Meeting of the Seminar for Arabian Studies Held in London, 24-26 July 2008, Oxford 2009, pp. 181-196.

Guest, R., "Relations Between Persia and Egypt Under Islam up to the Fāṭimid Period", in T.W. Arnold/R.A. Nicholson (eds.), A Volume of Oriental Studies, Presented to Edward G. Browne on his 6oth Birthday (7 February 1922), Amsterdam 1922, pp. 163-174.

Haarmann, U., "Regional Sentiment in Medieval Islamic Egypt", Bulletin of the School of Oriental and African Studies 43 (1980), 55-66.

Hassan, Z.M., Les Tulunides. Étude de l'Égypte musulmane à la fin du ixe siècle, 868-905, Paris 1933.

Hehn, V., Kulturpflanzen und Haustiere in ihrem Übergang aus Asien nach Griechenland und Italien sowie in das übrige Europa (Historisch-Linguistische Studien), Berlin 1911 (repr. Hildesheim 1963). 
Hodgson, M.G.S., The Venture of Islam. Conscience and History in a World Civilization. Vol. 1: The Classical Age of Islam, Chicago 1974.

Hoerder, D., Cultures in Contact. World Migrations in the Second Millennium, Durham 2002.

Hutchins, W.M. (transl.), Nine Essays of al-Jahiz (American University Studies. Series VII: Theology and Religion, 53), New York et al. 1989.

Irani, R.A.K., "Arabic Numeral Forms", Centaurus 4 (1955), 1-12 (repr. in M.H. Kennedy/ D.A. King (eds.), Studies in the Islamic Exact Sciences, Beirut 1983, pp. 710-721).

Karabacek, J.v., Papyrus Erzherzog Rainer. Führer durch die Ausstellung, Vienna 1894.

Kennedy, H., "Egypt as a Province of the Caliphate", in C. Petry (ed.), The Cambridge History of Egypt. Vol. 1: Islamic Egypt, 640-1517, Cambridge 1998, pp. 62-85.

Kennedy, H., The Armies of the Caliphs. Military and Society in the Early Islamic State, Abingdon 2001.

Kennedy, H., "The Decline and Fall of the First Muslim Empire”, Der Islam 81 (2004), 3-30.

Khan, G., Arabic Documents from Early Islamic Khurasan (Einstein Lectures in Islamic Studies, 3), Berlin 2014.

Khoury, R.G., Chrestomathie de papyrologie arabe. Documents relatifs à la vie privée, sociale et administrative dans les premiers siècles islamiques (Handbuch der Orientalistik. Ergänzungsband 2: Zweiter Halbband), Leiden/New York/Cologne 1993.

Kunitzsch, P., "The Transmission of Hindu-Arabic Numerals Reconsidered", in J.P. Hogendijk/A.I. Sabra (eds.), The Enterprise of Science in Islam. New Perspectives (Dibner Institute Studies in the History of Science and Technology), Cambridge Mass. 2003, pp. 3-21.

Lapidus, I.M., "The Evolution of Muslim Urban Society", Comparative Studies in Society and History 15 (1973), 21-50.

Lapidus, I.M., Islamic Societies to the Nineteenth Century. A Global History, Cambridge et al. 2012.

Lev, Y., "Coptic Rebellions and the Islamization of Medieval Egypt (8th-1oth Century). Medieval and Modern Perceptions", Jerusalem Studies in Arabic and Islam 39 (2012), 303-344.

Levi della Vida, G., "Appunti e questi di storia letteraria araba. 7: Numerali grechi in documenti arabo-spagnoli", Rivista degli Studi Orientali 14 (1934), 281-283.

Løkkegaard, F., Islamic Taxation in the Classic Period, with Special Reference to Circumstances in Iraq, Copenhagen 1950.

Morimoto, K., The Fiscal Administration of Egypt in the Early Islamic Period (Asian Historical Monographs, 1), Kyoto 1981.

Müller-Wodarg, D., "Die Landwirtschaft Ägyptens in der frühen 'Abbasidenzeit", Der Islam 31 (1954), 174-227; 32 (1955), 141-167; 35 (1958), 310-321. 
Naqvi, T.H., Art. "Islam and Migration", in I. Ness et al. (eds.), The Encyclopedia of Global Human Migration. Vol. 4: Ind-Rem, Chichester 2013, pp. 1873-1875.

Netton, I.R. (ed.), Golden Roads. Migration, Pilgrimage and Travel in Mediaeval and Modern Islam, Richmond 1993.

Pellat, C., Arabische Geisteswelt. Ausgewählte und übersetzte Texte von al-Ğāhiz (777869), unter Zugrundelegung der arabischen Originaltexte aus dem Französischen übertragen von Walter W. Müller (Bibliothek des Morgenlandes), Zurich 1967.

Rāgib, Y., "Contrat d'affermage d'un pressoir à huile en 205/821", Studia Iranica 11 (1982) (= Mélanges offert à Raoul Curiel), 293-299.

Rāgib, Y., Actes de vente d'esclaves et d'animaux d'Egypte médiévale (Cahiers des Annales Islamologiques, 23), vol. 1, Paris 2002.

Reinfandt, L., "Empireness in Arabic Letter Formulae", in S. Procházka/L. Reinfandt/ S. Tost (eds.), Official Epistolography and the Language(s) of Power. Proceedings of the ist International Conference of the NFN Imperium and Officium, Vienna 2014 (Papyrologica Vindobonensia, 8), pp. 333-346.

Sijpesteijn, P.M., "Building an Egyptian Identity”, in A.Q. Ahmed/B. Sadeghi/M. Bonner (eds.), The Islamic Scholarly Tradition. Studies in History, Law, and Thought in Honor of Professor Michael Allan Cook (Islamic History and Civilization, 83), Leiden/Boston 2011, pp. 85-105.

Sijpesteijn, P.M., "An Early Umayyad Papyrus Invitation for the Hajj”, Journal of Near Eastern Studies 73 (2014), 179-190.

Taxel, I./Fantalkin, A., "Egyptian Coarse Ware in Early Islamic Palestine, Between Commerce and Migration", Al-Masāq 23 ( 2011), 77-97.

Van der Veen, M., "When is Food a Luxury?", World Archaeology 34 (2003), 405-427.

Vanthieghem, N., "Les archives d'un maquignon d'Égypte médiévale”, Analecta papyrologica 26 (2014), 291-315.

Vroom, J.A.C. (ed.), Medieval and Post-Medieval Ceramics in the Eastern MediterraneanFact and Fiction. Proceedings of the First International Conference on Byzantine and Ottoman Archaeology, Amsterdam, 21-23 October 2011 (Medieval and Post-Medieval Mediterranean Archaeology Series, 1), Turnhout 2015.

Watson, A.M., Agricultural Innovation in the Early Islamic World. The Diffusion of Crops and Farming Techniques, 700-1100 (Cambridge Studies in Islamic Civilization), Cambridge et al. 1983 .

Yarshater, E., "The Persian Presence in the Islamic World", in R.G. Hovannisian/G. Sabagh (eds.), The Persian Presence in the Islamic World (Giorgio Levi Della Vida Conference, 13), Cambridge 1998, pp. 4-125.

Youssef-Grob, E.M., "The Earliest Paper Documents in the Vienna Collection Revisited", Chronique d'Égypte 90 (2015), 431-443. 